\title{
Paulina Duda*
}

\author{
SCREENING MIŁOSZ'S PHILOSOPHY: \\ THE MULTILAYERED CONSTRUCTION \\ OF TADEUSZ KONWICKI'S ADAPTATION \\ OF THE ISSA VALLEY
}

\begin{abstract}
Tadeusz Konwicki's adaptation of Czesław Miłosz's novel The Issa Valley is an adaptation of the latter's philosophy. Through a series of deliberately structured cinematic techniques, Konwicki creates a film that is a platform where two outstanding individuals meet, rather than a battlefield where each tries to surpass the other. By drawing on the paradigmatic structure approach created by Herbert Eagle, I demonstrate that The Issa Valley's meaning is created not on the level of the storyline but rather through the repeated cinematic segments that build a second "narrative" line within the film. Miłosz employs a similar strategy in his novel, which brings together both artistic styles, that of Miłosz and that of Konwicki. Furthermore, the similarities between the artists' biographies (childhood in Lithuania, life as refugees, a shared Romantic tradition) brings an additional layer to the adaptation. As a result, The Issa Valley film is a multilayered work that manifests not only Konwicki's artistic independence but also Miłosz's artistic philosophy and even the afterlife of his art.
\end{abstract}

Key words: Miłosz, Konwicki, adaptation, paradigmatic structure, Lithuania

Tadeusz Konwicki's adaptation of Czesław Miłosz's novel The Issa Valley (Dolina Issy, published in Paris in 1955) appears to be problematic for those who attempt to analyze it. "The question of fidelity" often encourages critics and viewers to judge a film adaptation's quality based on its resemblances to the text (Desmond and Hawkes 2006: 2). That is why many critics were primarily trying to understand whether Konwicki's adaptation was more a depiction of his own artistic style than an accurate adaptation of The Issa Valley. The fact that Konwicki himself is not only an unorthodox filmmaker but also an outstanding writer makes things even more complicated. Tadeusz Lubelski believes that Konwicki tailored Miłosz's novel to his own artistic sensitivity (Lubelski 2008: 472). Emilia Walczak thinks that in The Issa Valley film "there is more of Konwicki than of Miłosz"1 (Walczak 2007). The director himself, however, insists that his adaptation is truly faithful to Miłosz's work (Nowicki 1990: 157). Yet, it seems that another possibility should be considered here: Konwicki does

* University of Michigan, paulidud@umich.edu

1 All translations from Polish secondary sources are mine. 
not try to assert that his own artistic vision is superior or inferior to Miłosz's novelistic world; rather, he makes a film that is an intimate liaison between the two brilliant aesthetic styles and artistic philosophies of both Miłosz and Konwicki. The main scope of this paper is to examine how these two individual worlds coexist in a cinematic work. I will attempt to show that neither of these worlds tries to dominate the other; rather, they attempt to complement each other. In order to do so, the first part of the paper will focus on similarities among some elements of Miłosz's and Konwicki's literary works and biographies, and how such similarities are depicted in the film adaptation. In the second section, I will illustrate the 'cinematic tricks' Konwicki employs in order to express Miłosz's artistic philosophy and assert his own creative autonomy at the same time. In order to do so, I will use the paradigmatic structure approach created by Herbert Eagle (Eagle 1977: 45-57). Above all, my goal is to demonstrate that a film adaptation can be a platform where two outstanding individuals meet, rather than a battlefield where each tries to surpass the other.

\section{THE LITHUANIAN COMPLEX}

For some critics, the reason why Konwicki's film seems to be his own interpretation of Miłosz's novel rather than a faithful adaptation of the book is simple: Konwicki highlights themes that are very characteristic of his own art. He concentrates on the magical and demonic side of the Issa Valley, demonstrates the beauty of its landscapes, and underscores the most troubled characters. He also refers to the Romantic tradition, interrupts the main narrative line and, above all, obsessively signifies the role of memory. Indeed, for anybody who is familiar with Konwicki's art, these are the core elements of his whole artistic career, starting from his first novel The Marshes (Rojsty) and finishing with his latest film Lawa. Yet, at the same time, these components are common to Miłosz's novel as well - if not to the whole of his art. This means that Konwicki, through cinematic language, tries to find a shared platform of communication between them. The fact that their childhood years had a great deal in common was very important in shaping that platform. This chapter will concentrate on such similarities.

The fact that Miłosz and Konwicki were born in Vilnius area is significant. In Polish culture the city is regarded as the heart of Polish Romanticism. It is an almost mythical place. The two national "bards", Adam Mickiewicz and Juliusz Słowacki, were closely associated with Vilnius, which for many decades mantaintained its cosmopolitan character. It was home not only to Poles and Lithuanians, but also Jews, Russians, Belorussians and Germans. Moreover, it was Mickiewicz who initiated the myth of the lost Lithuanian land (Wroczyński 1996: 240). After World War II, however, Vilnius was no longer a Polish territory and became the capital of the Lithuanian Soviet Socialist Republic. Many Poles were forced to move to Poland and amongst them were Miłosz and Konwicki.

Such historical and cultural background shaped the early years of the two writers. They were both deprived of their roots and, in a way, identities, against their own will. Later on, the longing for lost childhood and land came to be a prominent theme in Miłosz's and Konwicki's works and it is also the main subject of The Issa Valley. It is in this subject that we 
encounter the most significant similarity between the two: the attempt to recapture a lost childhood in Lithuania. Although Miłosz once wrote, "It seems to me that my readers' penchant toward interpreting it as 'authentic' (while it is rather an exercise in disguised metaphysics) should be a lesson" (Miłosz 1988: 94), it cannot be denied that the novel bears some autobiographical traits. Yet, whether it is a purely autobiographical book or not does not matter; more important is the process of remembering, recapturing the place that was undoubtedly familiar to him. Indeed, that was the major reason why Konwicki, who once declared, "I write books and make films about myself" (Eberhardt 1962: 62-63), for the first time in his long cinematic career decided to adapt another writer's work. In a way, it could be considered a work about him too, something very close to his own experiences.

Aleksander Fiut writes that Miłosz's imaginary trips to the land of his childhood were attempts at regaining his creative power and fluency (Fiut 1985: 311). It is as if the memories of the most innocent period of a human life had some purifying qualities, as if the reconstruction of one's past could help in understanding one's present condition. In the case of The Issa Valley novel, it is crucial to remember that Miłosz does not try to tell the story of twelve-year-old Tomasz entirely from the boy's perspective. Although very often the reader sees the world through Tomasz's eyes, on many occasions the much wiser Narrator interrupts the flow of the boy's point of view to offer his own perspective. As he puts it, "in narrating such a story, one never knows whether to use the past or present tense, as if what has passed has not really passed as long as it survives in the memory of generations - or in the memory of one chronicler" (Miłosz 1981/1982: 8) ("Opowiadając nie wie się, jaki wybrać czas, teraźniejszy czy przeszły, jakby to, co minęło, nie było całkowicie minione dopóki trwa w pamięci pokoleń - czy tylko jednego kronikarza“ (Miłosz 1980: 10)). Right in the second chapter, the narrator lets readers know that all they are reading is told from the perspective of time. He calls himself "a chronicler" who not only tries to recall past reminiscences but also to understand present history through analysis of the past. It means that as a chronicler he must have accumulated more in-depth knowledge of life than his little protagonist has. Therefore, in the book not only a childish perception of reality is exposed ("The voices grew louder, the jokes more obscure, he was surrounded by adults and their silliness, and it bored him“ (Miłosz 1981/1982 128); "[...] żarty, których nie rozumiał, cała głupota dorosłych, nudził się“" (Miłosz 1980: 73)) but also that of a wise chronicler, the Narrator-Philosopher.

A very similar, yet much more complex, strategy is employed by Tadeusz Konwicki in his novel A Chronicle of Amorous Incidents (Kronika wypadków miłosnych). The main protagonist Wicio, just like Tomasz, lives near Vilnius and tries to take his first steps into the world of adults. But at some points he encounters a quite mysterious character who is actually himself from the future. Konwicki changes his narrative style throughout the novel, as some parts are written from the perspective of "old Wicio" from the future, interrupting the main narrative structure. It produces a similar impression to Miłosz's narrative. Thus, the effect is that although it is fascinating to see the boys' initiations into the adult world, their wiser alter egos become more appealing: they, in fact, possess much deeper knowledge of life.

And how is such a narrative strategy resolved in the film? Here, Konwicki really faithfully "translates" Miłosz’s (and his own) narrative style into cinematic language. In fact, he 
depicts Tomasz's and the other characters' adventures in Ginie, a little Lithuanian village, but seven times he interrupts the main plot line. All of a sudden, without signalling it, he inserts scenes where seven of the characters "from" Ginie appear in entirely new surroundings reciting Miłosz's poems: modern clothes and cities, high skyscrapers and traffic lights replace the Lithuanian manors in Ginie. Such a manoeuvre shifts the gravity from the scenes depicted in Ginie to the "present" world. Thus Tomasz, his grandparents the Surkonts, the suicidal Magdalena, crazy Baltazar, and all the numerous characters populating the Issa Valley become only a mere recollection, an echo of past times of the gentry in Lithuania: "their dramas are not the dramas of real people, but only a trace of already old-time and distant happenings" (Malatyńska 1982: 4). In fact, in Ginie the tangible world exists alongside the world of fantasies. In the movie we see Baltazar talking with the devil Niemczyk, and we see the ghost of Magdalena walking naked through the woods with a white horse. Many scenes in Ginie are shot slightly out of focus, making them somewhat unreal, lyrical and dream-like. This inevitably diminishes the credibility of the world of Ginie and underscores the seriousness of the seven characters reciting Miłosz's poems. Such an idea was not part of Miłosz's novelistic world but Konwicki's own interpretation of the book. Yet, it does not alter the Nobel Prize winner's message and it does not overshadow his work. Through an interrupted narrative structure, Konwicki signalizes that what is being watched is a recollection of somebody else reflecting on the necessities of remembering, rather than the story itself. The very fact that Miłosz in many places in the novel unmasks the presence of "a chronicler" seems to remain in keeping with such an argument.

I mentioned above the coexistence of real and supernatural forces in the Issa Valley. This should be noted as another parallel between Konwicki and Miłosz: even though the eternal beauty of the Lithuanian forests and meadows seems to be something that creates order and gives hope, these landscapes are, at the same time, populated by demons and devils. Miłosz writes, "The Issa Valley has the distinction of being inhabited by an unusually large number of devils” (Miłosz 1981/1982: 6), („Osobliwością doliny Issy jest większa niż gdzie indziej ilość diabłów" (Miłosz 1980: 5). Indeed, people in Ginie are surrounded by ghosts and demons, something that serves two purposes, one to introduce Lithuanian folklore and village superstitions, the other to serve as a "poetic justification for the extraordinary and tragic history of that land and its locals" (Sławińska 1985: 70). Thus, Ginie is not any sort of idyllic place. History did not spare the village: there are increasing nationalistic antagonisms between Lithuanians and Poles, and echoes of the First World War can still be heard. Therefore, Tomasz's childhood is not portrayed along the same line as Tolstoy's "Happy, happy, irretrievable time of [Nikolenka's] childhood!” (Tolstoy 1964: 11). Not because he encounters any injustice, but because he is surrounded by not yet understandable evil forces, which very soon will become part of his adult life.

Konwicki goes even further: such evil is much more perceivable throughout the early life of his protagonists, especially in the case of Polek (Konwicki 1965). The boy, in fact, experiences much more injustice than Tomasz. Although Konwicki does not write directly like Miłosz about the existence of devils and demons, the atmosphere of $A$ Hole in the Sky (Dziura w niebie) is filled with something not of this world. This effect is emphasized by the fact that the locals truly believe in superstitions. Their faith in God coexists with a faith 
in black magic. Polek's grandmother goes to church every Sunday, yet she is the one who believes only in a witch doctor's help when Polek falls ill. Exactly the same happens in the Issa Valley: when the priest Mankiewicz gets sick, a witch doctor is fetched to cure him. Not even mentioning the passage where the local men dig up Magdalena's body, then cut off her head and stab her heart with a wooden stick in order to prevent her ghost from tormenting others. For Tadeusz Konwicki this was another familiar element of an almost pagan place like Lithuania and perhaps that is why he highlighted this theme in his adaptation. Marek Sokołowski believes that he changed Miłosz’s fairy-tale like story into a stylised horror movie (Sokołowski 1995: 134). But is the novel really a fairy-tale? Certainly, the excessive descriptions of nature, detailed depictions of Lithuanian traditions and even Magdalena's love for the young priest create some sort of fairy-like world. But again, nature is absolutely indifferent to our lives and Magdalena's love ends with her suicide. Miłosz does not create a rosy picture of Ginie and its inhabitants; undoubtedly, Tomasz's world is quite innocent but only because he is still a child and a member of a well-off and kind family. Thus, most of the scenes with the boy are shot during the day and in sunlight, making the valley breathtakingly beautiful. But after dusk, some malevolent magical forces interact with people whom Tomasz knows very well. Baltazar is tormented by the memory of the murder that he committed, while Romuald engages in an inappropriate affair with his married aunt Helena. All these human miseries are taking over Konwicki's cinematic world for two reasons: from a cinematic point of view it is effective, and because those magical episodes mean "marvelousness thus art [...] that is shown to the world thanks to people such as Miłosz" (Nowicki 1990: 159).

Such frequent use of witchcraft unifies Miłosz's and Konwicki's art on another level as well: it simply continues the Romantic tradition. While reading The Issa Valley and Konwicki's A Dreambook for Our Time (Sennik współczesny) one cannot help thinking about Dziady by Adam Mickiwicz. The director admitted to himself: "Everything [in The Issa Valley film] happens between an evening and dawn [...] My idea was to make some sort of Dziady" (Mickiewicz 1950: 155). By doing this, he was able to emphasize their common cultural roots, the tradition which shaped their own artistic styles. Apart from the fascination with folklore, there is one more element that brings Romanticism to the fore, namely the myth of the fight for Polish independence, the glorification of human sacrifice and subordination of personal goals to greater national interests. The essence of Polish martyrdom became the November Uprising, also mentioned by Miłosz in The Issa Valley: "The girl's name was Emilia Plater, a distant relative of Thomas [...] which was supposed to be a source of great pride" (Miłosz 1981/1982: 68); ("Piękna panna nazywała się Emilia Plater i istniało między nią i Tomaszem odległe pokrewieństwo [...], z czego powinien był być dumny [...]“ (Miłosz 1980: 70)).

This passage places Miłosz in the Romantic tradition and - perhaps more importantly emphasizes the significance of remembering one's roots. Cherishing such a cultural heritage is crucial in the life of somebody like Miłosz, who remained a refugee for most of his life. Thus, he also mentions the January Uprising, another mythical example of sacrifice for the Polish Motherland: "As for the copper relief, it was once the property of his grandfather Arthur Dilbin, who in his youth had also chosen the forest. That was in the year 1863 ("Remember, Thomas - eighteen hundred and sixty-three...")"(Miłosz 1981/1982: 69); (“A ryngraf należał 
do dziadka Artura Dilbina, który w młodości też wybrał las, to był rok 1863 (zapamiętaj Tomasz: tysiąc osiemset sześćdziesiąty trzeci)“ (Miłosz 1980: 71)). He does not glorify the deeds themselves, but only demonstates that the memory of one's own history should not be forgotten. We see the same approach in Konwicki's The Polish Complex (Kompleks polski). Although he tries to deconstruct national beliefs that are overly exploited, he does not portray the leader of the January Uprising, Romuald Traugutt, in a negative light. He has much respect for Polish sacrifices regardless of his sentiments of condemnation towards war in general. In fact, analysing many elements of Konwicki's writing, Maria Janion demonstrated that he is a Romantic writer himself (Janion 2001: 645).

Depicting "Romanticism" in a cinematic work can be quite problematic, though. It has already been said that Konwicki tried to stylize Miłosz's novel to resemble Dziady; he created an atmosphere that could be associated with Romanticism. The second cinematic trick was less noticeable. Since the Nobel Prize winner only mentions the January Uprising in his narrative without linking it with the actual action (if we can call anything an action in the book), Konwicki had to use some sort of symbolism. There is one scene in the movie where Krzysztof Gosztyła, who plays Baltazar, recites Miłosz's poem Your voice (Twój głos). $\mathrm{He}$ is standing next to a gravestone with the date 1863 carved on the surface. The richness of meanings that this simple scenery evokes is undeniable: it brings to the fore the Romantic tradition, the significance of historic memory, sacrifices, the cruelty of death and inevitability of being forgotten (no names are carved on the gravestone, only the date). It seems that Konwicki almost accidentally mentions the January Uprising (just like Miłosz in his novel) trusting that somebody familiar with Polish history will understand such symbolism.

As demonstrated above, the parallels between Konwicki's and Miłosz's literary works are quite explicit. First of all, they both share the same personal feelings of loss: the loss of their childhood place and in a way the distortion of identity. In both of them, this very fact triggered some mechanisms that led to quite similar longings for what has been lost. They cannot, however, depict a purely innocent world of early years in the beautiful Lithuanian land because since they left it they have accumulated too many bitter experiences to believe in complete naivety. They underscore the huge importance of memory and of remembering one's cultural heritage. And this, in turn, makes them the heirs of Romanticism through the glorification of human sacrifices as well as folklore. All these elements, including the interrupted narrative structure, are faithfully depicted in Konwicki's adaptation without compromising his own artistic individuality. Yet, in order to fully grasp the meaning of his deliberately structured cinematic work it is necessary to analyze some segments of his film that occur in a repeated pattern. Although those elements are not a part of Miłosz's world presented in the novel, they show the meanings disclosed by the novel in a much more appealing way.

\section{PARADIGMATIC STRUCTURE}

The Issa Valley film consists of two parallel narratives. The action of the main narrative line is placed in the Lithuanian village of Ginie and it depicts different episodes from the lives of its inhabitants. That is what we could call the actual adaptation of Miłosz's novel. Yet, there 
is also the second narrative structure - or rather a series of similar scenes - which stands in stark contrast to the first one. The location changes - skyscrapers in New York replace beautiful Lithuanian landscapes, dream-like sequences give place to sharp images often shot in documentary style, and actors who played different roles in Ginie now in "normal" modern clothes recite Miłosz's poems staring straight into the camera, talking directly to us. Seven such "interruptions" were not part of the novelistic world, thus it created much confusion amongst the critics. In fact, it seems that they would rather prefer to just watch "real" pieces taken from the book (Nowicki 1990: 154-155).

Nevertheless, the series of seven visually similar "interruptions" - what I call the second narrative structure - really is an element of The Issa Valley book. On its own, the book does not present good material for a cinematic work: there is no development of the story or characters, and there is a lack of a main problem that could be tracked from the very beginning till the end. In other words, it is rather quite a common collection of well-exploited themes and episodes such as childhood in the countryside, nature and folklore. What make it special, though, are the language of the novel and the wise philosophy of the narrator. Thus, The Issa Valley by itself does not represent all dimensions of the Nobel Prize winner's art and philosophy; to put it better: "It is impossible to break into all the novel's hidden meanings directly [...] Here, very helpful happen to be [...] multiple linkages between The Issa Valley and the whole of Miłosz's poetry" (Fiut 1985: 312). Considering the way Konwicki adapted the novel, it seems that his understanding of it was similar to that of Aleksander Fiut. His film is not only an adaptation of the novel, but also its afterlife. The second "narrative line" is a deliberately structured, creative way of enhancing the full depth of Miłosz's art rather than a manifestation of his own individuality.

In one of his articles Eagle demonstrates that the meaning of a cinematic work can be derived not only from the story line but also from the way different, recurrent and deliberately structured paradigms are organised. "The recurrence of any formal feature - be it shape, colour, specific objects or categories of objects; particular lighting, movements, camera angle or camera motion, properties of focus or film stock; marked musical or verbal features on the sound track - can be used to organize and create meaning" (Eagle 1977: 46). The Issa Valley is a perfect example of a film that employs such a paradigmatic structure. In fact, the recurring scenes where actors recite Miłosz's poems create a set of meanings that underscore certain messages. To understand those messages it is crucial not only to analyze the scenes themselves but also to interpret the poems Konwicki has selected. By doing so it will become clear that everything in his composition is weighty, starting from who recites each poem and finishing on details visible in the background.

The image of a person reciting a poem appears for the first time right after the opening credits. The person is surrounded by skyscrapers with hundreds of lit windows, an unstoppable stream of cars, and flashing neon lights. Even though no sort of 'action' has developed yet on the screen, such an image is striking as it follows dream-like sequences of nature and characters dressed in interwar fashion. The juxtaposition is unmistakeable and it places socalled modern, industrial civilisation in a much more negative light than the village. At this point of the film we do not yet know what purpose such imagery serves but immediately after the appearance of a second reciter we can assume that Konwicki wanted to create a certain 
impression. The first poem is recited by Edward Dziewoński, who plays Tomasz's grandfather "in Ginie", and it starts with the words:

W mojej ojczyźnie, do której nie wrócę, Jest takie leśne jezioro ogromne, Chmury szerokie, rozdarte, cudowne Pamiętam, kiedy wzrok za siebie rzucę. $[\ldots]$

(W mojej ojczyźnie, Miłosz, 1981: 45)

\author{
In my homeland, where I shall never return, \\ There's a lake, in the forest, gigantic, \\ The clouds stretch wide, torn open, enchanted \\ I remember, if I cast my sight back. \\ $[\ldots]$ \\ (In my homeland, translated by Anthony Oscar \\ Miłosz, Miłosz 2008: 132)
}

The choice of poem is remarkable. The motif of a refugee is emphasized right at the beginning of the film. It suggests that all what we are about to watch is a projection of one's memory (Miłosz writes "I remember", "Pamiętam"). Not by chance the person reciting the poem is Mr. Surkont, who "in Ginie" plays a very respectable, well read man, familiar with history. He is also the one who introduces Tomasz to the fascinating world of history and nature, and so represents the "guardian" of collective memory. Apart from this, the poem concentrates on other key elements of both writers' art (and at the same time The Issa Valley): the feeling of loss of one's motherland ("In my homeland, where I will never return"; "W mojej ojczyźnie, do której nie wrócę") and even the Romantic tradition. Miłosz creates the image of a big lake in the woods whose bottom can disclose some secrets. This scene resembles Adam Mickiewicz's poem "Switeź". Yet, while Mr. Płużyn learned the history of the lake from a nymph, the poet can easily read himself from "his" shallow lake: he foresees some catastrophe and he understands the inevitability of some historical processes as well as the briefness of one human life. This interpretation is further developed by the second appearance of another reciter, Tadeusz Bradecki, who plays the priest Peikswa. The same pattern is repeated: the actor is reciting Miłosz's poems with New York City in the background:

Za polem, lasem i za drugim polem Ogromna woda białym lustrem lśni się. A na niej ziemia złotawym podolem Nurza się w morzu jak tulipan w misie. Ojciec powiada, że to Europa.

[...] (Z okna, Miłosz 1981: 95-96)

\author{
Beyond the field, a wood, and a second field, \\ The expanse of water, a white mirror, glitters. \\ And the golden lowland of the earth \\ Bathes in the sea, a half-sunken tulip. \\ Father tells us that this is Europe. \\ [...] \\ (From the Window, Miłosz 1996: 49)
}

Konwicki juxtaposes documentary footage of the crowded city and somehow alienated actor with the verses of a poem describing Europe in picturesque fashion. But it is important to realize that in the poem Europe is described by a father to his son, meaning that the father tries to appeal to a childish understanding of things, which in turn creates a simplistic image of the world (Fiut 1985: 331). The world is much more complex than that, which becomes clear to all attentive viewers and readers. Here, Konwicki seems to be playing with another set of meanings related to the word "father". Since in Miłosz's novel Tomasz grows up without his father, he could not be the one to explain to Tomasz the mysteries of life and the world.

\footnotetext{
2 Translation Copyright (C) 2008 by Anthony Oscar Miłosz.
} 
However, we could consider another possibility: in this context the father in the poem could very well also symbolize God the Father. Not by chance the person who recites the verses is the priest Peikswa "from Ginie", thus somebody who represents God on earth. Also, a priest in Poland is often called "a father". But at the same time Peikswa is a weak servant of God since he engages in a sinful sexual relationship with Magdalena. Such an interpretation creates a whole array of new meanings that align with Miłosz's philosophy depicted in the novel: "Teutonic knights were enemies. They were burning and murdering but at the same time they did believe in Jesus Christ and their act of baptising was saving from hell" ("Krzyżacy byli wrogami. Palili, mordowali, a przecie wierzyli w Jezusa, i chrzest przez nich udzielany chronił od piekła" (Miłosz 1980: 133). This indicates numerous contradictions: why has God allowed them to kill others, how is possible that their souls go to heaven? For Miłosz comprehends that very often religion offers superficial yet convenient answers. Just like the father in the poem gives a facile explanation of what Europe is, so does religion of any kind, when it comes to more complex questions. Again, it is significant that the scene with Bradecki follows Baltazar's (a murderer) conversation with the devil. The latter says, "Yes, I know you went to confession. But you're not so dumb as to believe you can make a clean breast of it in confessional. You lied" (Miłosz 1981/1982: 40); (“Tak, tak, spowiadałeś się. Ale taki głupi to ty nie jesteś żeby nie rozumieć, że nic tam przy konfesjonale nie potrafisz wybarmotać. Łgałeśs“ (Miłosz 1980: 31)). It is obvious that the act of confession cannot reconstruct one's sense of harmony after committing a crime; Baltazar could not be consoled by absolution, as human beings are much more doubtful, anxious and troubled by their obsessions and desires than it may seem from a religious point of view.

Immediately after the second "reciting scene", the viewer realizes that those "interruptions" serve more than educational objectives, as Tadeusz Lubelski believes (Lubelski 2008: 472). The reoccurrence of similarly structured images underscores all the meanings that the adaptation of the novelistic material alone could not convey. The third recitation by Józef Duriasz, who "in Ginie" plays a teacher and a nationalist advocating Lithuanian independence, confirms the metaphors already established. The actor walks through a film set - a camera crew is making a war film which is indicated by costumes and posters glued on the wall. This scene follows his conversation with Wackonis, who dropped a grenade into Tomaszek's bedroom as a result of his anti-Polish beliefs. Duriasz recites Miłosz’s poem “Obłoki”:

Obłoki, straszne moje obłoki, jak bije serce, jaki żal i smutek ziemi, chmury, obłoki białe i milczące, patrzę na was o świcie oczami łez pełnemi i wiem, że we mnie pycha, pożądanie i okrucieństwo, i ziarno pogardy dla snu martwego splatają posłanie, a kłamstwa mego najpiękniejsze farby zakryły prawdę. Wtedy spuszczam oczy i czuję wicher, co przeze mnie wieje, palący, suchy. O, jakże wy straszne jesteście, stróże świata, obłoki! Niech zasnę, niech litościwa ogarnie mnie noc.

(Obłoki, Miłosz 1981: 37)
Clouds, these terrible clouds,

how the heart beats, such rebret and sorrow of the earth, clouds, white and silent,

I look at you with terful eyes at dawn,

And I know that hubris, desire, cruelty, and a seed of contempt within me prepare a bed for the dead dream, the most beautiful colors of my deceit painted over the truth. I lower my eyes and feel the gale which blows through me, dry, burning. O, how terrible you are, guardians of the earth, clouds! Let me sink into sleep, Let the merciful night engulf me.

(Clouds, translated by Paulina Duda and Jodi Greig, unauthorized translation) 
Here, as in the case of The Issa Valley novel, nature seems to be an overwhelming force; beautiful yet indifferent to human sufferings and dilemmas. As Jan Błoński notes: "[Nature] doesn't provide a harmony and consent to one's own fate; just the opposite: it creates the sense of contradiction, death and inadequacy" (Błoński 1985: 74). But it also shows how miserable, weak and vicious a human being is when compared with nature. The author of the poem as well as the novel knows that all catastrophes are the result of human cruelty, greed and vanity. The "war-like" background in the film, which reminds us that people are responsible for all disasters, emphasizes such a message. In this scene Konwicki demonstrates another noteworthy cinematic trick. On the film set we see his face reflected in a camera. The director wanted to show that this Lithuanian world also belongs to him and that he takes full responsibility for what he has directed (Nowicki 1990: 158). Perhaps it also demonstrates that a cinematic work is a work of art that must be interpreted on different levels, as we watch a film within a film, poetry and prose within a movie, Lithuanian village people within somebody's memory. Above all this there is a director, who tries to coordinate those numerous spheres and depict them through means such as image, music, sound, scenery, camera angles and movement.

Demonstrating who the creator of the film adaptation is does not overshadow Miłosz's novel, though. Consequently, Konwicki incorporates another four of his poems into the film. And consequently each of them highlights Miłosz's philosophy through Konwicki’s cinematic style. The same motif of very powerful nature compared with human weakness appears in the next poem, Stonce (The Sun):

Kto chce malować świat w barwnej postaci Niechaj nie patrzy nigdy prosto w słońce. Bo pamięć rzeczy, które widzi, straci, Łzy tylko w oczach zostaną piekące. Niechaj przyklęknie, twarz ku trawie schyli I patrzy w promień od ziemi odbity. Tam znajdzie wszystko, cośmy porzucili: Gwiazdy i róże, i zmierzchy, i świty.

(Stońce, Miłosz 1981: 101)

\begin{abstract}
Whoever wants to paint the variegated world Let him never look straight up at the sun Or he will lose the memory of things he has seen. Only burning tears will stay in his eyes. Let him kneel down, lower his face to the grass, And look at the light reflected by the ground. There he will find everything we have lost: The stars and the roses, the dusks and the dawns.
\end{abstract}

(The Sun, Miłosz 1996: 71)

Here, as was the case in the previous "reciting scenes" it is important which particular character declaims a poem. In this place it is Jerzy Kamas, Romuald "from Ginie", perhaps the only adult in the Issa Valley who loves nature and respects it as much as Tomasz. It is not surprising that it is he who says, using Miłosz's verses, that a human being should be humble and never look straight into the sun, thus into the Absolute. The very source of creation is basic experience and nature, and they reflect the Absolute (Fiut 1985: 334). Therefore, the memory ("everything we have lost"/“wszystko, cośmy porzucili”) of one's childhood in the countryside to a great extent becomes a key in understanding the world and creation. It is at the same time one of the chief messages in The Issa Valley novel. Again, the reciter looks from his window at New York, an overwhelming, alienating urban landscape. The meanings here are derived, as before, from juxtaposing the imagery evoked by the poem with the shots of the city.

In the set of seven recurring paradigms there are another three that create a full complement of meanings. Marek Walczewski, the magician Masiulis, recites Miłosz’s poem in front of a changing background. 
It is crucial to catch all its elements to understand the lines:

Nie kochaj żadnego kraju: kraje łatwo giną.

Nie kochaj żadnego miasta: łatwo rozpada się w gruz.

Nie przechowuj pamiątek, bo z twojej szuflady

Wzbije się dym trujący dla twego oddechu.

Nie miej czułości dla ludzi: ludzie łatwo giną

Albo są pokrzywdzeni i wzywają twojej pomocy.

Nie patrz w jeziora przeszłości:

tafla ich rdzą powleczona

Inną ukaże twarz niż się spodziewałeś.

(Dziecię Europy, Miłosz 1981: 136-137)
Love no country: countries soon disappear

Love no city: cities are soon rubble.

Throw away keepsakes, or from your desk

A choking, poisonous fume will exude.

Do not love people: people soon perish.

Or they are wronged and call for your help.

Do not gaze into the pools of the past.

Their corroded surface will mirror

A face different from the one you expected.

(Child of Europe, Miłosz 1996: 109-111)

While Walczewski recites the first two lines we see a synagogue behind him. By using such suggestive symbol, Konwicki brings to the fore the Jewish nation, a theme that was very explicit in his own and Miłosz's writings. As noted before, the Vilnius area was a home for thousands of Jews; they contributed to Polish pre-war culture in a significant way. The terrible reminiscences of the genocide of World War Two have never left both artists, who felt responsible to preserve the memory of their Jewish countrymen. Therefore, Miłosz concludes in his poem that it is not worth it to get attached to cities, countries, places and even people because they all perish, they cease to exist so easily, exactly as Polish Jews did. The poet's voice sounds bitter; he understands that people contribute to such destructive processes. He even denies the necessity of remembering one's past: souvenirs of the past bring only misery, pain and disappointment; the final recapitulation of one's life is always pitiful and much different from what we expected, therefore it is better not to look back. Later on, the background to the movie changes and we see a Catholic church as well as an Orthodox church. This reminds us of the multireligious character of the Issa Valley as well as different ways of living one's life (Nowicki: 1990: 157). So far all of the "reciting scenes" have been incorporated into the film in a deliberately structured emotional order. Here, we encounter feelings of disappointment and bitterness only to arrive at a state of rebellion against death in the next poem:

Przeklinaj śmierć.

Niesprawiedliwie jest nam wyznaczona. / Błagaj bogów, niech dadzą łatwe umieranie. / Kim jesteś, te trochę ambicji, pożądliwości i marzeń / nie zasługuje na karę przydługiej agonii. / Nie wiem tylko, co możesz zrobić, sam, ze śmiercią innych, / dzieci oblanych ogniem, kobiet rażonych śrutem, oślepłych żołnierzy, / która trwa wiele dni, tu, obok ciebie. /

Bezdomna twoja litość, nieme twoje słowo, / i boisz się wyroku, za to, że nic nie mogłeś. /

(Twój głos, Miłosz 1981: 151)
Curse death.

It is unjustly determined for us. /

Beg the gods to send an easy death. /

Who are you?

A few ambitions, lusts and dreams, /

do not deserve the penalty of prolonged agony. /

I just don't know what you alone can do

with the death of others, /

children inundated by fire,

women wounded by shot, blinded soldiers, /

with that death that lasts many days,

here, next to you. /

Your compassion is homeless, your words mute, / And you fear condemnation for your helplessness. /

(Your voice, translated by Paulina Duda and Jodi Greig, unauthorized translation) 
The poem is recited by Krzysztof Gosztyła, who is standing next to a gravestone with the date 1863 carved on its surface. The linkages between this date and Polish Romanticism have been already discussed. The poet, however, also tries to see death in more universal light. The scene follows the death of Tomasz's grandmother, who was slowly and painfully passing away. Thus the poet revolts against such a miserable end to human life; he believes that our small, pitiful dreams and desires do not deserve to end in prolonged agony. This could refer not only to Tomasz's grandmother but also to the reciter, Baltazar. The crime that he has committed initiated his slow death; his agony, anxiety, rebellion against one's limits and fate, desperate attempts to comprehend why he killed another human being, all these internal torments slowly lead to his destruction and eventual death. Yet, this does not exhaust all meanings that can be derived from the poem and at the same time from The Issa Valley book. The poet admits that above all perhaps the most disturbing experience is to watch the death of other people - because we cannot help them, we are impotent and powerless. Our consoling words and feelings of compassion mean nothing. Thus, death is cruel and unjust, which little Tomasz realizes watching his dying grandmother: "He looked at her, her chest fighting for one more breath, so small and defenseless against the monstrosity bearing blindly down...” (Miłosz 1981/1982: 212); (“jej pierś walczyła o jeszcze jeden oddech, zobaczył ją małą, bezbronna, wobec straszliwości, która zgniatała ją obojętnie [...]“ (Miłosz 1980: 144).

Such rebellion against injustice and the pitifulness of death changes into profound and bitter awareness of the end of one's life in the last scene. Igor Smiałowski's (the priest Mankiewicz) words underscore the deep disappointment of a pilgrim, artist and a human being at the same time:

Tak mało powiedziałem.

Krótkie dni.

Krótkie dni,

Krótkie noce,

Krótkie lata.

Tak mało powiedziałem,

Nie zdążyłem.

Serce moje zmęczyło się

Zachwytem,

Rozpaczą,

Gorliwością,

Nadzieją.

Paszcza lewiatana

Zamykała się na mnie.

Nagi leżałem na brzegach

Bezludnych wysp.

Porwał mnie w otchłań ze sobą

Biały wieloryb świata.

I teraz nie wiem

Co było prawdziwe.

(Tak mało, Miłosz 1981: 181).
I said so little.

Days were short.

Short days.

Short nights.

Short years.

I said so little.

I couldn't keep up.

My heart grew weary

From joy,

Despair,

Ardor,

Hope.

The jaws of Leviathan

Were closing upon me.

Naked, I lay on the shores

Of desert islands.

The white whale of the world

Hauled me down to its pit.

And now I don't know

What in all that was real.

(So Little, Miłosz 1996: 229) 
The poem as the last element of a series of recurrent "reciting scenes" fits in very well with the whole paradigmatic structure. Here, the poet reaches the climax of his emotions: he is now facing the end of his life aware that he did not manage to express everything that he wanted; the years were too short and he grew tired by experiencing different emotions thus he now feels a lack of fulfillment. In a way he summarizes all the motifs that appear throughout a series of other poems. Again, the poet is a pilgrim, who spent his life wandering around the world ("The white whale of the world/Hauled me down to its pit") but such trips did not bring anything substantial to his existence. There is some sort of regret - perhaps being away from his homeland deprived him of something crucial and truthful; maybe all he has left there was more real than his frantic desire to experience life and the world. He says: "I said too little" which could also refer to the people he had left without expressing his gratefulness, perhaps his love. In fact, before this scene Konwicki repeats very significant imagery once: the moment when little Tomaszek overcome by happiness embraces his mother, whom he had not seen for several years. Therefore, to be a pilgrim also deprives one of developing deep relationships with very close people. The poet also uses biblical images ("whale", "Leviathan"), as well as symbols taken from literature ("desert islands") that demonstrates his belonging to both spheres: religious and artistic (Fiut: 1985, 254-255). These motifs also appeared in previous verses. The images that Konwicki shows in the last "reciting scene" also summarize the main motifs of Miłosz's quoted poems and at the same time his novel. Viewers see beautiful and powerful mountains as well as New York. Yet, for the first time the city is bathed in the red light of dusk. This draws a parallel with numerous scenes "in Ginie" where after the sunset evil forces always populated the valley. Moreover, the obsessive musical motif that consistently underscores sinister situations "in Ginie" is also used here as a soundtrack. This musical motif has been so persistent throughout the film that now it is impossible to miss its association with something negative. This impression is highlighted by the fact that so far all recitations were accompanied by a sung version of each poem, which added to the lyricism of each scene. Here, however, instead of delicate song we hear disturbing music. The recitation is followed by the image of a girl dressed in a traditional Lithuanian outfit, standing by the ocean in New York. Yet, the ocean is grey, the city is alienating, the Lithuanian traditional outfit is only a small, almost insignificant characteristic of this foreign country. Such an ending not only emphasizes Miłosz's philosophy enclosed in The Issa Valley but also brings to the fore his own biography, by the partly autobiographical character of the last poem (Fiut 1985: 254) as well as by images constructed by Konwicki, that refer to their common experiences. Thus, the whole structure of recurrent "reciting scenes" enhances the meanings of the novel.

Analyzing Konwicki's adaptation without making references to Miłosz's and his own writings misses the point. All of Koniwcki's cinematic works are a combination of audiovisual tools and literature. In The Issa Valley he concentrates on his and Miłosz's similar experiences and shared artistic motifs that derived from those experiences: childhood in the Vilnius area, the beauty of the Lithuanian nature, magic and superstitions, the Romantic tradition and the role of memory. But more importantly, Konwicki incorporates seven of Miłosz's poems into his adaptation which not only reveal the full depth of the novel but also demonstrate its afterlife. Such stylistic strategy turns his adaptation into a multilayered work, which brings to 
the fore Miłosz's prose, poetry, autobiography and even the impact of his writings in the future. In fact, the Nobel Prize winner was reflecting on this in his novel. "And here the chronicler stops writing and tries to depict people who will visit this place after many, many years. Who are they? What keeps them busy?"; ("Tutaj kronikarz zatrzymuje pióro i stara się sobie przedstawić ludzi odwiedzających to miejsce kiedyś, po wielu, wielu latach. Kim są? Czym są zajęci?“" (Miłosz 1980: 149). Konwicki's unorthodox adaptation pays homage to Czesław Miłosz and at the same time becomes the very expression of his own artistic style.

\section{BIBLIOGRAPHY}

\section{PRIMARY SOURCES ${ }^{3}$}

Konwicki, Tadeusz. 1965. Dziura w niebie, Warszawa: Iskry.

Konwicki, Tadeusz. 1985. Kronika wypadków miłosnych, Warszawa: Czytelnik.

Konwicki, Tadeusz. 1989. Kompleks polski, Warszawa: Wydawnictwo Alfa.

Mickiewicz, Adam. 1950. Pan Tadeusz, Warszawa: Książka i Wiedza.

Miłosz, Czesław. 1980. Dolina Issy, Paryż: Instytut Literacki.

Miłosz, Czesław. 1981/1982. The Issa Valley, New York: Farrar, Straus, Giroux.

Miłosz, Czesław. 1981. Poezje, Vol. 1, Paryż: Instytut Literacki,

Miłosz, Czesław. 1987. Poezje, Vol. 2, Paryż: Instytut Literacki.

Miłosz, Czesław. 1996. Poezje wybrane. Selected Poems, Kraków: Wydawnictwo Literackie.

Miłosz, Czesław. 2008. In my homeland, in: Ewa Lempp, Krajobrazy literackie. Fotografia 1985-2007, Kraków: Universitas, p. 132.

Tolstoy, Leo. 1964. Childhood. Boyhood. Youth, London: Penguin Cassics.

\section{SECONDARY SOURCES}

Błoński, Jan. 1985. Dolina Issy, in: Jerzy Kwiatkowski (ed.), Poznawanie Miłosza. Studia i szkice o twórczości poety, Kraków: Wydawnictwo Literackie, pp. 74-91.

Desmond, John and Peter Hawkes. 2006. Adaptation: Studying Film and Literature. Boston: McGraw-Hill.

Eagle, Herbert. 1977. The Syntagmatic and Paradigmatic Axes in Closely Watched Trains, in: Ben Lawtoand and Janet Staiger (eds), Film Studies Annual, part 1, New York: Redgrave, pp. 45-56.

Eberhardt, Konrad. 1962. Aktorzy filmu polskiego, Warszawa: Wydawnictwo Artystyczne i Filmowe.

Fiut, Aleksander. 1985. Wygnanie z raju, in: Jerzy Kwiatkowski (ed.), Poznawanie Miłosza. Studia i szkice o twórczości poety, Kraków: Wydawnictwo Literackie, pp. 311-354.

Janion, Maria. 2001. Tam gdzie rojsty. Przypadek romantycznego mediumizmu, in: Maria Janion (ed.), Prace wybrane. Romantyzm i jego media, Vol. 4, Kraków: Universitas, pp. 642-668.

3 Copyright for the whole Miłosz's literary heritage holds The Milosz Estate. 
Lubelski, Tadeusz. 2008. Historia polskiego kina, Katowice: Videograff II.

Nowicki, Stanisław. 1990. Pół wieku czyśćca. Rozmowy z Tadeuszem Konwickim, Warszawa: Oficyna Wydawnicza.

Malatyńska, Maria. 1982. Portret artysty w plenerze, "Życie Literackie" 40: 4.

Miłosz, Czesław. 1988. The Novel in Poland, "Daedalus" 3: 93-96.

Sławińska, Irena. 1985. To jest daleki kraj, in: Jerzy Kwiatkowski (ed.), Poznawanie Miłosza. Studia i szkice o twórczości poety, Kraków: Wydawnictwo Literackie, pp. 68-76.

Sokołowski, Marek. 1995. Między pragnieniem a spetnieniem. Filmowa adaptacja Doliny Issy, in: Andrzej Staniszewski (ed.), Studia i szkice o twórczości Czesława Miłosza, Olsztyn: Wyższa Szkoła Pedagogiczna, pp. 133-142.

Walczak, Emilia. 2007. Pamięci doliny. Konwicki ponad podziałami, http://konwicki.art.pl/ interpretacje/pamiecidoliny/ [20.04.2011].

Wroczyński, Tomasz. 1996. Tradycja, tęsknota i mistyfikacja. Rzecz litewska Tadeusza Konwickiego, in: Eugeniusz Czaplejewicz and Edward Kasperski (eds), Kresy w literaturze. Twórcy dwudziestowieczni, Warszawa: Wiedza Powszechna, pp. 240-253.

\title{
FILMOWANIE FILOZOFII MIŁOSZA: WIELOWARSTWOWA BUDOWA FILMOWEJ ADAPTACJI DOLINY ISSY AUTORSTWA TADEUSZA KONWICKIEGO
}

\begin{abstract}
Filmowa adaptacja powieści Czesława Miłosza pt. Dolina Issy, którą w 1982 roku wyreżyserował Tadeusz Konwicki, jest w istocie interpretacją filozofii polskiego noblisty. Poprzez serię przemyślnie zastosowanych technik filmowych Konwicki tworzy film będący raczej platformą, na której dwie wybitne artystyczne indywidualności się spotykają, a nie polem bitwy, gdzie jedna usiłuje pokonać drugą. Wzorując się na modelu struktury paradygmatycznej Herberta Eagle'a, demonstruję w moim artykule, że znaczenia Doliny Issy Konwickiego konstruowane są nie tylko na poziomie fabuły, ale także przez wielokrotnie powtórzone segmenty filmowe, które tworzą jakby drugą linię narracyjną w filmie. Miłosz używa podobnej strategii w swojej powieści, co łączy oba style artystyczne: Miłosza i Konwickiego. Co więcej, podobieństwa pomiędzy biografiami obu artystów (dzieciństwo na Litwie, życie uchodźców, wspólna tradycja romantyczna) wnosi dodatkową warstwę znaczeniową do adaptacji. W efekcie Dolina Issy Konwickiego jest wielowarstwowym dziełem manifestującym jednocześnie niezależność artystyczną Konwickiego, jak również filozofię Miłosza, a nawet pogłosy recepcji jego dzieł.
\end{abstract}

Słowa kluczowe: Miłosz, Konwicki, adaptacja, struktura paradygmatyczna, Litwa 